To cite this article: Mustika Imanda, Nurlisa Ginting and Beny O.Y Marpaung (2022). STUDY ON THE POTENTIAL ARRANGEMENT OF THE KRUENG IDI RIVERSIDE AREA, EAST ACEH REGENCY, International Journal of Education and Social Science Research (IJESSR) 5 (1): 01-07

\title{
STUDY ON THE POTENTIAL ARRANGEMENT OF THE KRUENG IDI RIVERSIDE AREA, EAST ACEH REGENCY
}

\author{
Mustika Imanda $^{1}$, Nurlisa Ginting ${ }^{2}$ and Beny O.Y Marpaung ${ }^{3}$ \\ ${ }^{1}$ Master's Degree Program of Architecture, Faculty of Engineering, \\ Universitas Sumatera Utara, Medan, Indonesia \\ ${ }^{2}$ Master's Degree Program of Architecture, Faculty of Engineering, \\ Universitas Sumatera Utara, Medan, Indonesia \\ ${ }^{3}$ Master's Degree Program of Architecture, Faculty of Engineering, \\ Universitas Sumatera Utara, Medan, Indonesia
}

DOI: http://dx.doi.org/10.37500/IJESSR.2022.5101

\begin{abstract}
The rationale of this paper is the growing concept of waterside development that has been widely adopted by many countries in the world. Waterfront area is part of the physical elements of the city that have the potential to be developed into a living area (livable) and a gathering place for the community. In its development, the Concept of Waterfront in several countries in the world has a concept that tends to be the same. Waterfront development should be able to be optimally processed to highlight the potential and character of each region. To present the concept of effective and functional development, it needs to be controlled by considering the good aspects in terms of physical or non-physical. With an emphasis on Environmental Musts and Functions. Aspects of consideration are obtained based on the study of literature. The results of the study showed that in the development of the waterfront it is important to harmonize between the city/land and water so that both can play a reciprocal role. The reciprocal relationship between the two can realize a well-organized environment and also presents functions that accommodate activities in the waterside area more effectively and functionally.
\end{abstract}

KEYWORDS: Waterside, Waterfronts, Krueng Idi

\section{INTRODUCTION}

The arrangement of riverside areas, is an integral part of the urban arrangement, especially when the river becomes an important part of the life of the surrounding community, the character of settlements in Indonesia which is still very dependent on the use of rivers, contributes to the decline in the quality and carrying capacity of the environment, and decreases the visual quality of the city.

The condition of large cities that experience declining quality causes urban settlements to become slum environments bringing new problems, such as poor physical development of cities, providing poor 
visual effects, lower levels of public health as a result of settlement conditions that are not in accordance with health standards and provide a poor social and economic impact of the community. The city of Idi is the capital of East Aceh Regency which is located on the coast of Sumatra Island. The city is directly adjacent to the Strait of Malacca on the north side. Geographical conditions like this cause the city of Idi to have a close relationship with the territorial waters. As a coastal city, Idi has many areas directly adjacent to the waters, one of which is the Krueng Idi River.

Krueng Idi River has the main function as the main drainage channel of the city. Krueng Idi River is the main channel that becomes the path through the water before heading to the sea. The above conditions have a function that is quite vital for the city of Idi. However, the Krueng Idi River was unable to function optimally because there was a lot of sedimentation so that the volume of water accommodated was reduced. In addition, there are also wild and rundown buildings built by the community around the riverbank without paying attention or heeding the existing regulations. The existence of these wild buildings further makes tumult in the riverbank area. So that resulted in many adverse effects both for the city of Idi as the capital of East Aceh regency, even there were some large flash floods that hit the surrounding area due to the overflow of this river.

The problem with this study is What potential can be developed in the Krueng Idi Riverside Area in East Aceh Regency and How the Structuring Strategy based on Potential Studies in the Krueng Riverside Area in East Aceh Regency. The purpose of this research is to Analyze the potential development of the Krueng Idi Riverside Area in East Aceh Regency and to Review potential Structuring Strategies in the Krueng Idi Riverside Area in East Aceh Regency.

The Study of the Potential Structuring of the Krueng Riverside Area in East Aceh Regency has research limitations, namely, among others The research was conducted only in 2 villages located right in the river area, namely Gampong Aceh Village, Idi Rayeuk District of East Aceh Regency and Gampong Keude Aceh Village, Idi Rayeuk District of East Aceh Regency. The Study of The Potential Structuring of The Krueng River Area in East Aceh Regency only covers 2 aspects, namely Geographical aspects and Urban Aspects. The study includes 7 (seven) parameters, namely Physical condition of the environment, flora and fauna, Economics, Social and cultural, Housing and settlements, Facilities and infrastructure, and Legality and management of the area (authority).

\section{METHOD}

This research is a qualitative descriptive study, by making observations, interviews, and documents. The method is combined to describe what happened and obtain facts related to identifying the potential of nature, location, culture, human resources and evaluating the principles and criteria of waterfront development in the Krueng Idi Riverbank area, systematically, factually, and accurately about the facts, properties, and relationships between the phenomena investigated. The descriptive method is a method of examining the status of a group of people, an object, a set of conditions, a system of thought, 
or a class of events in the present [1]. The purpose of this study is to create a systematic, factual, and accurate description, description, description, or painting of the facts, properties, and relationships between the phenomena being investigated.

Detailed research will explain the condition and conditions of the development of the Krueng Idi River area, accompanied by data and facts related to land use patterns in the riverbank area, the potential of the region, policies, and the role of institutions in the development of the Krueng Idi Riverside area, and several other factors that affect, among others, the attitudes and behavior of the community, tourists, the role of institutions, and community participation.

In addition to being described as being described, qualitative research methods are also used in this research. This method can be defined as a process of investigation to find out social problems or human problems. The process of investigation is carried out based on an overview of the state of the related study object. The results of the investigation can be analyzed in a form of described with a report on the detailed view of the source related to the object of the study [2]. Qualitative descriptive research methods attempt to translate the phenomena that are around, then perform various types of observations, and data collection. The data obtained from this qualitative research is descriptive data in the form of oral and written words, as well as the behavior of the people studied.

\section{RESULTS AND DISCUSSION}

East Aceh Regency located in the eastern part of Aceh Province has close access to North Sumatra Province. This is beneficial for the development of this region because based on the geographical location of East Aceh Regency directly adjacent to the Strait of Malacca, so it has direct access to other countries, especially Malaysia. Idi Rayeuk subdistrict is located at the coordinates 04 $43^{\prime} 19.46^{\prime \prime}$ 04'59'17.84", and 04 43'19.46" - 04'59'17.84". With an area of $79.60 \mathrm{Km}^{2}$ with a surface height ranging from 0 to $100 \mathrm{~m}$ above sea level. Consisting of 3 mukim and 35 villages/gampong with the border of the northern subdistrict directly adjacent to the strait of Malacca, the east borders the District of East Idi, the west borders the District of Darul Aman, and the south borders the district of Idi Tunong and Darul Ihksan District.

\subsection{Results of Study Through Observation Techniques}

From the results of the location observations obtained an overview of the condition of the Krueng Idi Riverside Area as follows:

1) Residents of the Krueng Idi River Bantaran Area are very heterogeneous, both in social and cultural aspects. Nevertheless, the harmony between the citizens is well established. Communication of residents is accommodated in seating facilities and also small stalls that are deliberately built across the house, on the riverbank within a certain distance (Figure 3.1.1). This facility is used to just chat while residents enjoy a cup of coffee, and other relaxing activities. 


\section{International Journal of Education and Social Science Research}

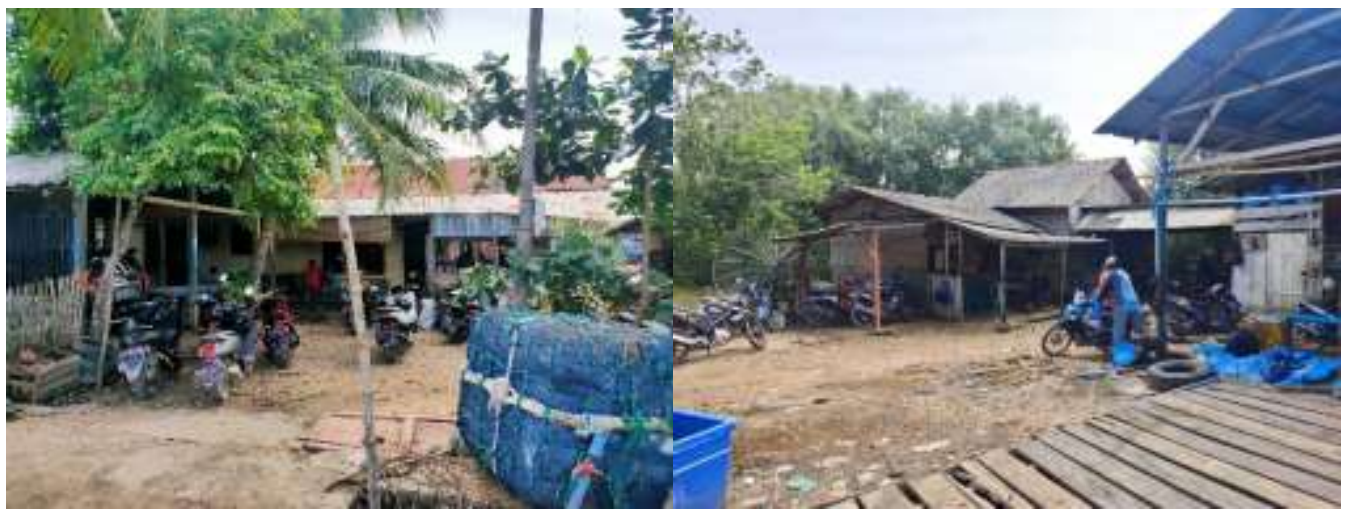

Figure 1. The Condition of Stalls On The Riverbank

2) Most of the residents of Krueng Idi Riverside Area are immigrants from outside the city of Idi East Aceh but still within the scope of Aceh Province.

3) In terms of economy classified as low-income group, it can even be said in the poor group (Figure 3.1.2).

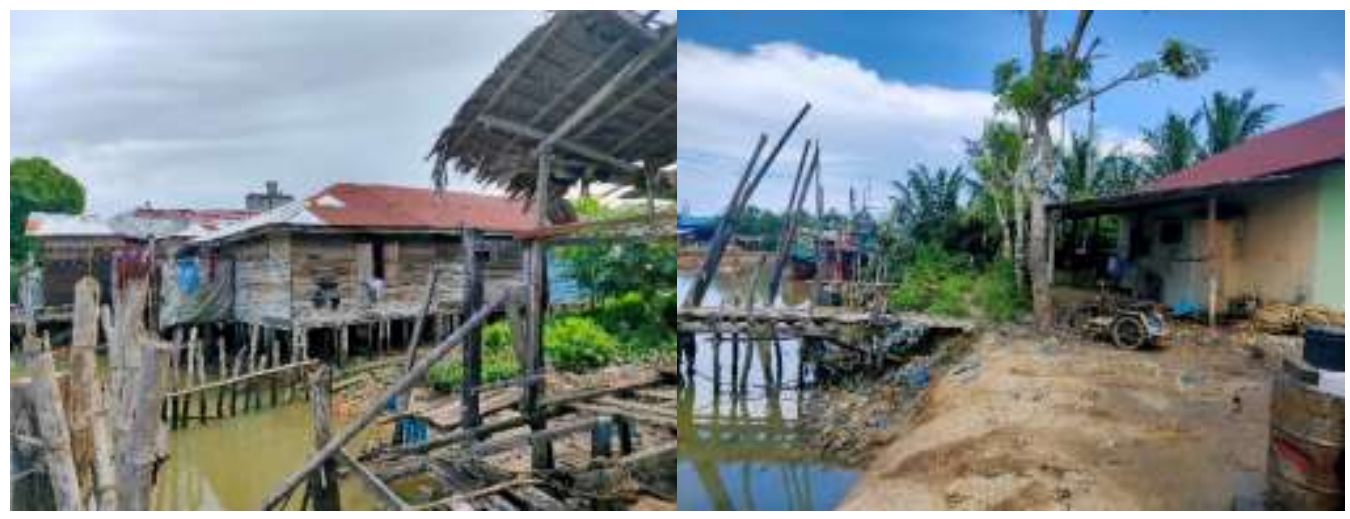

Figure 2. Environmental Conditions on The Riverside

4) Only a small percentage have a steady job as a fisherman (Figure. 3.1.3). while most work odd jobs by taking advantage of the opportunity. Stalls as part of community economic activities have sprung up in the region.

5) The quality of HUMAN RESOURCES is relatively low with most elementary school educated.

6) Public awareness to maintain the environment is actually quite good, as evidenced by the creation of a garden in the neighborhood (Figure 3.1.4). Just because of the limited land owned, garbage disposal still needs to be handled. 
7) Awareness of the importance of health has also been understood, but because of its limitations, both economic and social, the handling of MCK is still not optimal.

8) The use of the river to support daily activities is still high, either just to waste hajat or to make a living with 'nambang' activities or netting fish.

\subsection{Results Through Interview Techniques}

Walkability is an important concept in a sustainable urban design approach. It's a measure of how friendly an area is to pedestrians. Walkability has many benefits for health, environment, and economy [3]. Walkability Analysis interview process is conducted informally where the researcher asks questions spontaneously or naturally, in a normal atmosphere, relaxed and reasonable as a conversation in everyday life to anticipate respondents who do not have competence in the scientific field that concerns this research so that the meaning of the question is submitted can be understood by them, as well as to get a description of the environmental conditions of the riverbank in accordance with the assessment of the community and the needs and desires of the community towards the environment of the riverbank.

From the interview process conducted found several problems, namely Generally the outside community accesses the location by using two-wheeled vehicles (private vehicles) because of the elongated route, and the width of the road area in a limited area, the majority of respondents suggested appropriate arrangements for pedestrians and cyclists, this is certainly also much more efficient and effective for users/visitors to enjoy the riverbank area. While the local community revealed that road conditions do not allow for public transportation (difficult to reach), they tend to walk and use two wheels to access their residence and the surrounding area. As for people who have four-wheeled vehicles limited only for work purposes (workers between goods).

The local community also revealed that the area tends to be less friendly because there are still frequent security disturbances, especially at night, which are carried out by teenagers both from the right environment and from outside. The number of non-activity areas, poor environmental conditions, local community habits such as garbage disposal and MCK activities in the river, and the lack of lighting facilities in the area cause the area less friendly and less safe to visit.

Generally, respondents feel uncomfortable with the condition of open space around their dwellings, especially the riverside area, this is due to lack of lighting at night, lack of storage facilities, and drainage problems that are often clogged causing standing water in people's homes and the number of livestock that are free to roam in the area. The lack of pedestrian/street furniture facilities, the chaotic and slum environmental conditions create a sense of discomfort for visitors from outside the area to come or just pass through the area, the majority of respondents suggested the physical arrangement of the environment in the form of slinging and drainage facilities, as well as the addition and arrangement 
of vegetation in the area, a clean and shady environment is certainly the main thing in creating the comfort of an environment.

\subsection{Results of A Study on Local Regulations on The Arrangement of Riverside Areas}

Directive of RTRW of Idi Rayeuk city and RTBL of Idi Riverside Area, that the location is directed as a tourist area, protected area / Green belt and Green Open Space of the city which aims to control the utilization of space and create an organized, sustainable, cultured Krueng Idi Riverside Area so as to increase economic vitality and life of the people of Idi Rayeuk City. Planning for the development of riverside areas along the city of Idi Rayeuk is divided into 3 classifications, namely tourism, trade and services, and education. The research area is included in the grouping of main zones and support zones with the direction of tourist, cultural, and culinary areas.

The concept of culture and culinary is carried out by inviting community components such as the household, government, and private sector industry in an effort to create new activities and jobs that are useful in the region such as water tourism and various community cultural festival events. The development plan with the concept of a waterfront city helps control activities/habits and resuscitate the community to maintain and preserve the river area, as well as efforts to socialize improvement programs and the formation of environmentally caring communities.

\section{CONCLUSIONS}

Based on the findings of the analysis, the following conclusions can be drawn as the final results of the research findings:

1. The potential in the krueng idi riverbank area is quite good with the existence of structurally dominant elements in the form of bridge buildings and naturally the existence of vacant land that is useful as a transition zone, visual river landscape, and skyline. This area is a border that is on the edge of the Bridge so that it has the potential as a connecting gate with the area and the surrounding activity centers. However, the dense occupancy and orientation that turns its back on the river, land transfer, unmanageable environment, and lack of regional infrastructure lead to low quality of visual details and environmental shaping elements, such as street furniture completeness, materials/layouts, textures, ornaments, and character of spaces formed by environmental conditions and the façade of surrounding buildings. Areas are not easily accessed physically and visually by the general public. Achievements that can only be accessed by foot and two-wheeled vehicles.

2. From the results of interviews with several people who live in the krueng idi riverbank area can be drawn to the conclusion that the krueng idi riverbank area is: 
a. less easy because it does not fit the concept of walkability which is Limited areas are only accessible by foot and private vehicles and have not yet accessed supporting infrastructure. Road conditions in the area have fully experienced pavement but the slum environment affects the pattern of user movement. In short, outside users have no desire to explore the area for a long time. The main access to the riverbank is still mostly in the form of neighborhood streets and quiet alleys on the sidelines of buildings.

b. less connected because there is no gate to the location, the main access to the riverbank in the form of secondary local roads, neighborhood roads, and alleys on the sidelines of the building. Noncontinuous road routes and lack of infrastructure that supports space user activities, repair efforts that are still per spot-spot, and the use of different materials cause the function of public space is not optimal and not integrated with other networks.

c. less friendly because Local people's habits, environmental conditions, activity patterns, movement of space users, and the existence of infrastructure that tends to be centralized at certain points cause the area less friendly and less safe to visit. local communities, environmental conditions, activity patterns, movement of space users, and the existence of infrastructure that tends to be centralized at certain points cause areas to be less friendly and less safe to visit.

d. less comfortable because of lack of pedestrian facilities and street furniture. The area is only comfortable to visit during the day, at night the area of deserted riverbank conditions and sleeves with very minimal lighting that only comes from the lighting of local dwellings, garbage disposal habits, and MCK activities on the riverbank also cause discomfort for visitors from outside the area to be in the area.

e. less clear because Road areas in the area have largely experienced pavement, both permanent pavement with asphalt and temporary with paving, most neighborhood streets in the area do not have a name and formal limits coupled with the lack of road sign facilities, the completeness of regional infrastructure causes unclear routes that affect the movement patterns and interest of visitors to the area.

\section{REFERENCES}

[1] Nazir, Moh. Metode Penelitian, Ghalia Indonesia (2005)

[2] Creswell, John, Research Design: Qualitative and Quantitative Approaches, London: SAGE Publications (1994)

[3] Grant, J.A\& Associates. Glenferrie Road Precinct Walkability Study Final Report (2008) 